\title{
WISDOM IN INVERTED COMMAS: \\ GREEK COMEDY AND THE QUOTABLE MAXIM
}

\author{
Matthew Wright* \\ University of Exeter, UK
}

\begin{abstract}
Greek comedy is full of quotable maxims. According to a literal reading, the comedians might be seen as custodians of traditional gnomic wisdom, along with their tragic counterparts. Nevertheless, it is argued here that maxims in comedy are different from maxims in other contexts. Comic maxims typically appear 'within inverted commas', not just in a literal sense (because of their inherent 'quotationality') but in a figurative sense (because of their pervasive irony and selfconsciousness). Examples from Menander, Antiphanes, Diphilus and others are used to demonstrate that the comedians can be seen as playing around with the content and form of traditional wisdom. Sometimes they seem to be poking fun at the maxim as a medium of expression, or at tragic maxims, or at the habit of quotation itself.
\end{abstract}

Ancient Greek comedies were full of maxims encapsulating traditional wisdom in a conveniently memorable and quotable form. Modern scholars conventionally refer to such maxims as gnomai, though the Greeks themselves were not consistent in their use of terminology. (Words such as gnome, paroimia, logos and apophthegma are found more or less indiscriminately throughout the literary tradition, in much the same way as the categories of 'proverb', 'maxim', 'saying', 'generalization' and 'aphorism' overlap with one another in standard English usage. ${ }^{1}$ ) In terms of their

\footnotetext{
*m.wright@ex.ac.uk

${ }^{1}$ See Russo (1997), esp. 50-59, on the use of such terms as hypotheke, paroimia, apophthegma, gnome, legomenon, etc. Aristotle (Rhet. 2.1394a22-6, 3.1413a15) explicitly distinguishes between gnomai (general statements) and paroimiai
} 
content, all such maxims are closely comparable: they purport to convey universal insights into human life, and they tend to be utterly traditional in the sentiments they express; originality is seldom a distinguishing feature. Comic maxims range across the conventional territory of Greek popular morality, including such subjects as wealth, love, marriage, friendship, familial relationships, and the vicissitudes of fortune. They differ slightly in terms of their form - for instance, some are considerably longer or shorter than others, some of them explicitly refer to their own traditional content using words such as logos or paroimia, ${ }^{2}$ and some of them contain rhymes, wordplay, or other rhetorical features - but they are all characterized by a pithy or epigrammatic turn of phrase.

In fact, these maxims can be seen as possessing a quality called quotationality. Gary Saul Morson, who coined this expression, defines it as follows: it 'confers on phrases a degree of otherness', and it is said to create an 'aura' or a vague feeling that something is being quoted, even when the utterance in question is newly created. Not every utterance that is quoted necessarily possesses quotationality: in this respect Morson usefully distinguishes between 'quotations' (which do) and 'citations' (which do not). But a phrase that does have this quality will typically be 'short', 'memorizable', 'interesting', 'complete in itself', 'shared', and 'potentially autonomous' (of speaker, author or context); it will also possess an inherent 'doubleness' or ambiguity, either because it can function in or out of context, or because it has an implied 'shadowy second speaker, who is not identical to the speaker of the source' ${ }^{3}$

Comic maxims conform to this definition of quotationality. They are short and memorable; they have a high degree of iterability; they tend to stand out from any surrounding text because of the use of framing devices (e.g. their positioning at the

(proverbs), but this distinction is not widely observed by other writers. Note that both

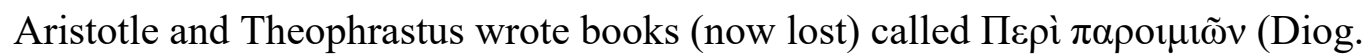
Laert. 5.26, 5.45).

${ }^{2}$ E.g. Alexis fr. 88, Mnesimachus fr. 9, Philemon fr. 139, Platon, Phaon fr. 188.3-4, Menander, Aspis 189-91 and Koneiazomenai fr. 1.

${ }^{3}$ Morson (2011) 37-8, 81-5, 96-7. Cf. Garber (2003) 16 on the 'ventriloquism' of quotations, or Empson (1930) 51 on 'lines that stand out...like quotations on a tombstone'. 
start or end of speeches, or the fact that they normally fill complete lines of verse, facilitating maximum detachability); they have an inherent doubleness about them, allowing them to function both in and out of context; they are often intertextual in a broad sense, in that they are adapted from earlier texts or the tradition of Greek popular wisdom more generally; they seem to blur the narratological category of voice; they also blur the boundaries between past and present, or between the world of the play and the real world of the audience. By including numerous maxims in their plays, the Greek comedians might seem to be encouraging us to view them as custodians of traditional wisdom, along with their epic and lyric predecessors; but, more importantly, they are conferring a high level of quotability on their own work.

One of the biggest questions posed by this material concerns the importance of literary genre when interpreting maxims. That is, are comic maxims significantly different from maxims in other literary or non-literary contexts? I suggest that the answer is yes. Comedy is not like other genres. Its ubiquitous humour and irony inevitably affect our response to anything that we encounter there. As I have argued elsewhere, one of the defining features of Greek comedy is that it typically presents its subject-matter, as it were, inside inverted commas - that is, in a manner that is pervasively self-conscious or ironical. ${ }^{4}$ The comedians tend to take material from elsewhere in literature or life and play around with it, subjecting it to ludic, deflatory or critical treatment. Comedy characteristically invites its audience to see familiar phenomena in unfamiliar ways, or to laugh at things that are normally perceived as serious.

In this article I suggest that the comedians are not simply presenting their audience with traditional wisdom in neatly packaged gobbets, as other poets do, in order to lend authority and moral depth to their work. It is possible to read many comic maxims absolutely straight, as genuine ethical guidance for life, and most critics seem to do exactly that, ${ }^{5}$ but I prefer to read them more obliquely. All the

${ }^{4}[\quad]$.

${ }^{5}$ For the view that Menander's comedy aims at serious social, ethical or philosophical teaching, see (e.g.) Barigazzi (1965); Cinaglia (2014); Hurst (2015, esp. 33-50 on maxims). Cf. Green (1990) 67 for the view that Menander's maxims are 'moralizing asides thrown in to give these puffball plays extra weight'. See below on the gnomic tradition relating to Menander and Epicharmus. 
comic maxims discussed here should be imagined as framed by a large pair of inverted commas - because of their inherent 'quotationality', because they stand out from their dramatic context as detachable lines, because they reiterate familiar material from a wider literary or gnomological tradition, and above all because they are distinguished by a recurrent irony and self-consciousness. In many instances, as I shall demonstrate, the comedians seem to be playing around with, or questioning, the content and form of traditional wisdom. Sometimes they seem to be going even further, poking fun at the maxim as a medium of expression or, more radically, at the habit of quotation itself.

It is significant that several critics and theorists treat the maxim as a distinct literary genre. ${ }^{6}$ This is a useful concept for our purposes, because it enables us to draw analogies with comedy's treatment of other literary genres such as tragedy, epic, lyric poetry, and so on. Comedy's relationship to these other genres has been widely interpreted in terms of parody or pastiche, or, alternatively, as a flexible and variously nuanced series of intergeneric dialogues. ${ }^{7}$ I suggest that comedy can similarly be seen as engaged in an ongoing dialogue with the maxim. The distinctively comic version of the maxim works by evoking, absorbing, parasitizing, distorting, subverting, or criticizing a genre that was extremely familiar from other types of literature and social situations. $^{8}$

This is not to claim that every single maxim in comedy functions in exactly the same way; nor is it to deny any serious ethical or didactic purpose to the comic genre. I strongly suspect that many of the comedians were indeed being frivolous and silly, with no particular moral point or message to convey. But if some of them did have a serious purpose, it will probably not emerge through a solemn, literal reading of their maxims. Rather, by creating an ironical distance between themselves and the traditional material, the comedians can be seen as challenging their audiences to think more carefully about the content of traditional popular wisdom and the form in which

\footnotetext{
${ }^{6}$ E.g. Shapiro (2000), Martin (2009); cf. Morson (2012) 11-19.

${ }^{7}$ See, most recently, Bakola, Prauscello and Telò (2013). Cf. Genette (1997) 1-4 for the concept of 'architextuality' as a sub-branch of intertextuality (genres or generic conventions are seen as 'architexts' determining the formal features of a new text). ${ }^{8}$ I am concerned with the literary context here, but cf. Martin (2009) on 'wisdom performance' and 'social proverb use'.
} 
it was passed down. Instead of simply presenting us, as other poets do, with supposedly universal wisdom, glib generalizations or clichés, certain comedians may have been prompting us to ask more profound questions about the way in which maxims were used by other people, the nature of true wisdom, or the ambivalent relationship between 'universal' ethical questions and specific situational contexts.

\section{COMEDY AND QUOTATION CULTURE}

Most of the comic maxims we now possess, in the guise of 'fragments', have survived precisely because they were quoted by other writers within antiquity. The quotation of decontextualized extracts - including the use of florilegia or anthologies of maxims was a widespread practice throughout antiquity, for which evidence exists as early as the fifth and early fourth centuries BC. ${ }^{9}$ It is obvious that, for many Greeks, selective or non-linear reading was a normal way of engaging with texts (especially poetic and dramatic works).

The popularity of excerption as a reading habit in the fourth century is highlighted, and made fun of, in the following extract from a scene in Menander's comedy Aspis (407-15). Here the slave Daos - who is attempting to bamboozle another character, Smikrines, into thinking that a 'tragic' event has taken place quotes a large number of gnomic verses excerpted from several tragedies by different authors:

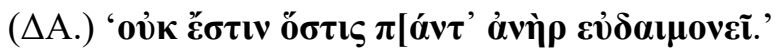

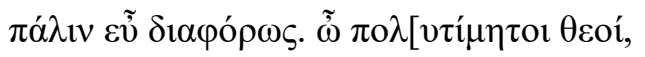

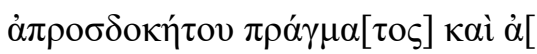

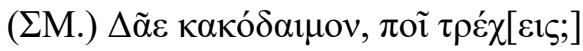
$(\Delta \mathrm{A}$.)

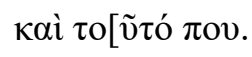

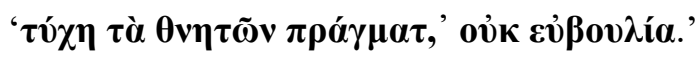

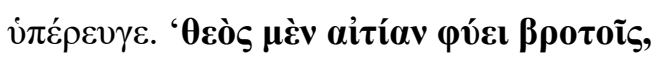

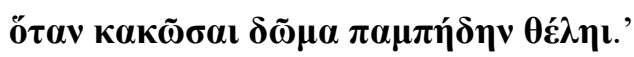

\footnotetext{
${ }^{9}$ e.g. Ar. Ach. 398-400, Wasps 1259-60 (cf. 725-6); Hippias DK86 B6; Xen. Mem. 1.6.14; P1. Leg. 811a-b, Phaedr. 228b, 267c; Arist. Rhet. 2.21.2-4, 1394b-95a, Topics 105b; Aesch. In Ctes. 135; Philochorus apud Suda $\Phi$ 441; cf. Isoc. To Nicocles 43-4 (quoted above). For recent discussion see Konstan (2011).
} 


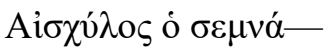

$(\Sigma \mathrm{M}$.

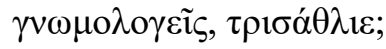

( $\triangle$ A.) 'ä́rı

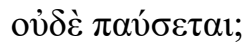

(Daos:) 'There is no man who is fortunate in all respects'. ${ }^{10}$ Once again, excellently expressed! Oh, ye greatly honoured gods, what an unexpected event, and [...]

(Smikrines:) Daos, you wretch, where are you running off to?

(Daos:) ... and then there's this one: 'Chance, not planning, governs human affairs'. ${ }^{11}$

Absolutely brilliant! 'The god sows guilt in mortal men, whenever he wishes to destroy a house utterly'. ${ }^{12}$ That one's from Aeschylus, the one who solemnly-

(Smikrines:) Quote maxims, will you? Thrice-wretched creature!

(Daos:) 'Incredible, irrational, terrible'... ${ }^{13}$

(Smikrines:) Won't he ever stop?

These verses are non-consecutive, irrelevant to the comic context, and completely unrelated to one another, but the crucial point is that they already resemble extracts from a gnomic anthology. Menander and his audience were evidently well

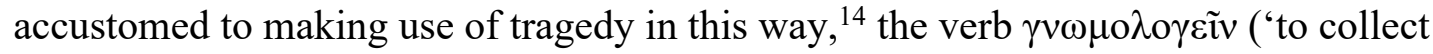
maxims' vel sim.) was obviously in common usage, and the excerpts in question had already become 'popular tags' (in the words of the play's most recent commentator). ${ }^{15}$

This scene, alongside other examples from comedy, shows us how tragedy was being treated as a repository of quotations from an early date. ${ }^{16}$ But if we look for evidence of quotations from comedy itself, a striking fact emerges. Apart from the later anthologizers, who treated comic drama as a rich mine of quotable wisdom (and

\footnotetext{
${ }^{10}$ Eur. Stheneboea fr. 661.1 Kannicht.

${ }^{11}$ Chaeremon, Achilles Thersitoktonos fr. 2 Snell.

${ }^{12}$ Aesch. Niobe fr. 154 Radt.

${ }^{13}$ Carcinus fr. 5b Snell.

14 The habit of quoting maxims or other decontextualized excerpts from tragedy provides the basis for humour in other comic passages: e.g. Diphilus, Synoris fr. 74, Nicostratus fr. 29, Philippides fr. 18. Wright (2013) 615-17 argues that these comedians are undermining or mocking this selective mode of reading texts.

${ }^{15}$ Ireland (2010) 100-102; cf. Cusset (2003) 144-58.

${ }^{16} \mathrm{Cf}$. Section IV below.
} 
thus preserved the majority of our surviving fragments), most writers throughout the classical period are conspicuously lacking in gnomic quotations from comedy. This implies that comedy was not generally treated in the same way as other types of literature. When we look at the comedians' immediate contemporaries in the late fifth and fourth centuries, their lack of interest in comic maxims is striking. Forensic orators, in particular, quote gnomic verses from a wide range of epic, tragic, and lyric poets, but not a single line from comedy. This may be due to the fact that comedy was regarded as too political to be used in a courtroom setting, ${ }^{17}$ but it may equally suggest that comedy was widely perceived to be lacking in seriousness. This is certainly the opinion of Isocrates, who contrasts comedy with writers such as Hesiod and Theognis and other poets whom he regards as 'the best advisors for human life'

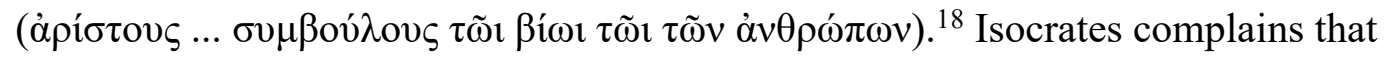
most readers ignore the wisdom that is to be found even in morally edifying poets such as these:

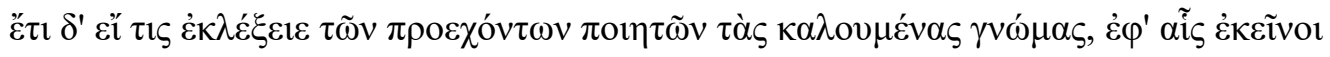

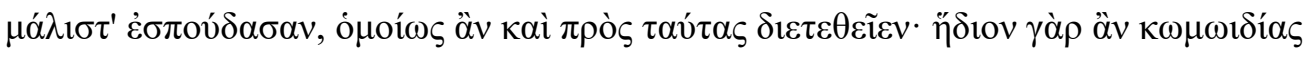

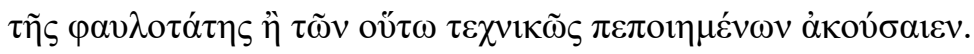

Even if someone were to make a selection of the so-called gnomai of the leading poets, the ones that they have composed with especial care, people would treat these in just the same way - for they would much rather listen to the most wretched comedy than to poetry composed with such artistry.

This passage confirms that maxims, more than any other passages from poetry, were excerpted and quoted as a source of wisdom or advice for life, but it also implies that - in Isocrates' eyes, at least - 'wretched' comedy was excluded from the category of serious poetry. The reluctance of other writers to quote comic maxims seems to suggest that they mostly shared Isocrates' viewpoint.

\footnotetext{
${ }^{17}$ The view of Perlman (1964), esp. 161-5. Cf. Scafuro (1997) on tragic quotations in oratory.

${ }^{18}$ Isoc. To Nicocles 43-4: see Hunter (2014) 77-8 on the further implications of this passage. Cf. Isoc. Peace 14 for denial of comedy's status as a respectable genre.
} 
In this respect another very striking fact needs to be emphasized. Although socalled 'middle' and 'new' comedy abound in maxims, there are almost no maxims to be found in fifth-century comedy, apart from quotations or parodies from other literary sources. ${ }^{19}$ This seems to mark a significant development in the genre over time. Various explanations might be suggested, including the emergence of the epigram as a prominent literary form in the fourth century, or the growing interest in quotation culture and anthologies during the same period. But in large part this development may be due to the fact that fourth-century comedy was even more obsessed with tragedy and paratragedy than earlier comedy had been. ${ }^{20}$ In other words, because tragedy (especially Euripidean tragedy, a favourite source of humour) incorporates a huge number of maxims, so too did later comedy, in an attempt to become - or to seem - more 'tragic'. It might be thought that comedy had suddenly grown up and become serious, taking on some of the ethical or didactic function traditionally ascribed to tragedy. But had comedy really changed so much in the space of a few decades? Perhaps not.

A couple of comedians in particular, Epicharmus and Menander, have been seen as especially fond of maxims as a vehicle for pursuing serious ethical concerns. These two poets were writing at different periods and in very different contexts, but they pose similar problems. Their names came to be attached, by later writers and scholars, to large anthologies of moralizing maxims, but little if any of the content of these anthologies is authentic: they apparently consist of haphazard collections of

${ }^{19}$ I have identified only the following: Ar. Birds 451-2, Thesm. 198-9 (quoting/parodying Agathon), 411-13 (quoting/parodying Euripides), Knights 88-94, fr. 976 (= Clem. Alex. Strom. 6.24.9, doubtfully assigned; may be from Epicurus); Chionides fr. 8 (= Vitruvius 6 pr. 3, doubtfully assigned: also attributed to Eupolis [fr. 494], Crates [fr. 60], Aristophanes [fr. 924]); Cratinus fr. 28 (quoting a pre-existing logos), fr. 203 (discussed below); Eupolis fr. 366; Platon fr. 190; Metagenes fr. 19 (parodying Homer); Theopompus fr. 35 (quoting/parodying Euripides). Arnott (2000) notes that Stobaeus, who frequently excerpts passages from fourth-century comedy, does not include gnomic material from old comedy.

${ }^{20}$ On tragedy and paratragedy in fourth-century comedy, see Gutzwiller (2000), Cusset (2003), Farmer (2017). 
verses from a variety of authors, genres and periods. ${ }^{21}$ I ignore this problematic material here, preferring to focus exclusively on Athenian comedy and on maxims which can confidently be attributed to Menander's plays. I shall return to Menander in more detail below, but it is worth observing here that his complete surviving texts, line for line, contain surprisingly few maxims. Given that many scholars have seen Menander as engaging seriously with Peripatetic thought, it is also important to note that his maxims are not especially interesting from an ethical or philosophical point of view. As David Bain has observed of Menander's supposed moralizing purpose, 'this was a case easier to sustain when all we had of him was fragmentary quotation' ${ }^{22}$

The fragmentary state of our sources means that we have to exercise caution when looking for patterns or drawing conclusions, but there are signs that other comedians may have been even more noteworthy than Menander in their use of maxims. The remains of Philemon, for instance, include many gnomic lines revealing a penchant for paradox, an unexpected avoidance of clichés, and a certain amount of original imagery, all of which features seem calculated to breathe new life into hackneyed themes: Philemon's maxims may well have offered more food for thought than those of Menander. ${ }^{23}$ Several comedians from the earlier decades of the fourth century, such as Amphis, Alexis, Anaxandrides and Antiphanes, are particularly well represented by gnomic fragments, and Antiphanes even wrote an entire comedy called Paroimiai. ${ }^{24}$ This work is briefly mentioned by Athenaeus:

${ }^{21}$ See [Epicharmus] frs. 244-73 (cf. frs. 100, 214), with Olson (2007) 9-10, 52-63; on the Pseudepicharmeia in relation to the Sicilian dramatic tradition see Bosher (2014) 85-88. On the Menandrou gnomai see Pompello (1997), Liapis (2002), Pernigotti (2008).

22 Bain (1983) xix.

${ }^{23}$ See esp. Philemon, Ephebos fr. 28 (sailors are not the only people who are afflicted by storms), Pyrphoros fr. 75 (it is viewers, not artists, who create beauty in artworks), incert. fab. frs. 92 (poverty can be a desirable state of affairs), 97 (justice is not the same thing as avoiding crime), 119 (envy can be a good thing rather than an evil to be

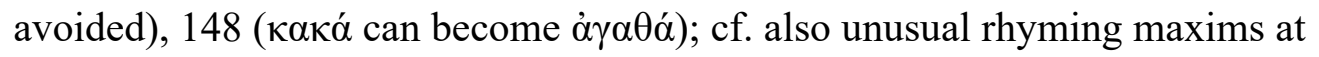
Epidikazomenos fr. 23 and incert. fab. fr. 135.

${ }^{24}$ Antiphanes frs. 186-7 (Athenaeus 2.60d-e); cf. Machon's Chreiai, a third-century work which may or may not have been a comedy: see Kurke (2002). Note also a 


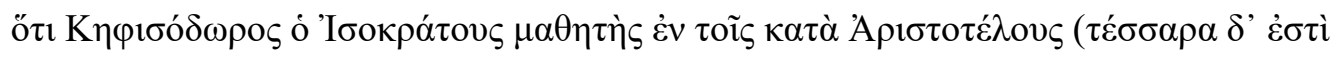

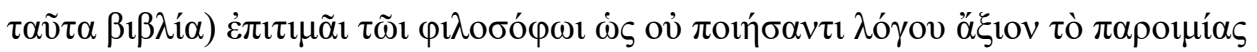

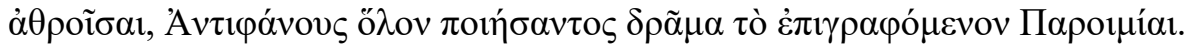
Cephisodorus, the pupil of Isocrates, in his Criticism of Aristotle (a work in four books), takes the philosopher to task for not having judged it worth while to collect proverbs, whereas Antiphanes wrote a whole play entitled Paroimiai.

Almost nothing survives of this comedy, alas, but it evidently based its whole plot and conception on the idea of quotable maxims and proverbial wisdom. Its title suggests that the chorus members actually represented personified maxims - a witty physical embodiment of an abstract concept, for which parallels can be found in the Dissoi Logoi of Aristophanes' Clouds or the letters of the alphabet in Callias' Grammatike Tragoidia. It seems likely that Antiphanes' play incorporated a significant metapoetic element, drawing special attention to the maxim as a topos or a source of humour in its own right. Here, if anywhere, maxims are being paraded before us wearing ironical inverted commas.

So far, then, I have been outlining a general case for regarding the characteristically comic maxim as a ludic, distorted version of an ostensibly familiar form. It could be added that the comedians' deployment of maxims is essentially metaliterary in purpose. They are drawing their audience's attention (either implicitly or explicitly) to quotation culture and the habit of selective excerption; they are actively participating in quotation culture by the way in which they formulate certain verses so as to stand out as quotations even in their original setting; by inviting the audience to see all these maxims as appearing within 'quotation marks' they are challenging them to think about what this might mean in terms of interpretation; and they are obliquely using these maxims as a form of self-referential commentary on contemporary reading practices. The following sections develop this general case via discussion of specific examples.

\section{READING MAXIMS IN AND OUT OF CONTEXT}

curious dramatic work from seventeenth-century France - La comédie de proverbes which may be similar to Antiphanes' play in its conception: see Kramer (2003). 
Dramatic maxims have a dual function and purpose: they are formulated so as to be readable either within a specific plot context or out of context as autonomous utterances. Sometimes there will have been a significant discrepancy or dissonance between these two levels of interpretation. The meaning of a maxim might be altered, enhanced or undercut in a variety of ways, depending on its precise situation and timing within a play's plot, or on the identity and status of the speaker. It seems to me that comedy, considerably more than tragedy, typically exploits this sort of dissonance to create a pervasive sense of irony or inconsistency. ${ }^{25}$

To take a single, telling example: the well-known Menandrean one-liner ôv oi

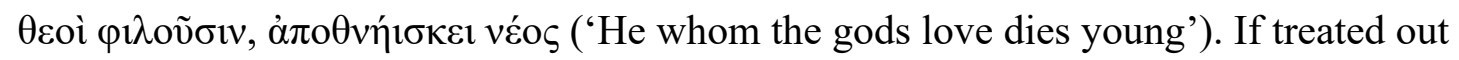
of context as a self-contained utterance, this lends itself to being read as a poignant generalization about promising lives cut short. Indeed, it became famous, in both ancient and modern times, as an autonomous maxim: it was repeatedly quoted or paraphrased by such writers as George Herbert, Lord Byron, and Oscar Wilde, ${ }^{26}$ and it has been described as 'the expression of a refined, thoughtful, and very sympathetic mind, touched with melancholy but remarkably free from passion or sensuality'. ${ }^{27}$ Nevertheless, the verse evidently made a rather different impression in its original dramatic setting, where it was not a lament for doomed youth but a sarcastic insult directed at an old man by a cheeky slave. The play Dis Exapaton survives only in woefully fragmentary form, but we have Plautus' Latin adaptation of the scene in question (Bacchides 816-21):

\section{quem di diligunt}

${ }^{25}$ Tragic maxims can also be read in or out of context, but any resulting dissonance tends to be less radically ironical: see e.g. Lardinois (2006).

${ }^{26}$ Menander, Dis Exapaton fr. 4 K-A (125K), quoted in antiquity by Stobaeus 4.52b.27, [Plut.] Consol. Ad Apoll. 119e, Clem. Alex. Strom. 6.2 and others (see PCG ad loc.). On the verse's modern incarnation(s) see Oxford Dictionary of Proverbs ${ }^{6}$ (Oxford, 2015) 130; cf. G. Herbert, Jacula Prudentum 1094, Byron, Don Juan IV.xii; Wilde reworked the line as 'those whom the gods love grow young' and 'those whom the gods hate die old': see Wilde (2007) 166-7. On this and other Menandrean maxims that circulated in decontextualized form cf. Nervegna (2013) 207-8. ${ }^{27}$ Powell and Barber (1929) 9. 
adulescens moritur, dum valet, sentit, sapit.

hunc si ullus deus amaret, plus annis decem,

plus iam viginti mortuom esse oportuit.

terrai $<$ iam $>$ odium ambulat, iam nil sapit

nec sentit, tantist quantist fungus putidus.

(Chrysalus:) He whom the gods love dies young, while he still has his health, sense, and wits. This fellow here, if the gods had loved him, ought to have died more than ten - no, more than twenty - years ago, but as it is, he's still walking around as a blight on the earth, he's lost his wits and his senses, and he's about as much use as a mouldy mushroom.

In this instance the undercutting effect created by the context and speaker is particularly marked; but no doubt the same sort of dissonance between generalizing maxim and specific context was, in varying degrees, frequent throughout comedy.

In all but a few cases we can read these maxims only in their decontextualized/fragmentary form. However, the few complete or partially preserved plays of Menander offer us an opportunity to compare and contrast the function of maxims in and out of context. ${ }^{28}$ It is hard to generalize on the basis of such a small sample, but a few interesting tendencies emerge. First of all, and most strikingly, the effect created by maxims within a particular scenario tends to be much less definitive or less confident than the effect of their decontextualized equivalents. These supposedly universal statements of wisdom and truth are uttered in a way that makes them come across as tentative or provisional. Often the speakers seem to be using maxims in an attempt to persuade others to see things their way when the truth of a situation is in doubt, or in an attempt to bolster up their own authority and status when they are under threat in some way, or in a spirit of self-consolation when the events going on around them seem chaotic or terrible. ${ }^{29}$ It is almost as if these characters are hoping that the very act of stating these 'truths' could make them true. The second notable tendency is that maxims are often uttered by the 'wrong' people - young,

\footnotetext{
${ }^{28}$ See Cusset and Lhostis (2011), with reference to Dyskolos, Samia and Aspis. ${ }^{29}$ E.g. Aspis 189-93; Dyskolos 129-31, 271-87, 767-71, 789-90, 860-5; Samia 140-3, 163-5, 206-9, 340-2.
} 
foolish, immoral or servile characters - rather than by their older, wiser, loftier counterparts. ${ }^{30}$ Again, this undermines the authority of the words uttered.

We might have expected to find some contrast between the maxims dished up during the earlier part of a play (when everyone is stumbling about in confusion and error) and those offered towards the end of a play (when it is finally clear what has been happening, and some sort of moral lesson might reasonably be drawn from the events). But there is not a single example of this sort of effect in the surviving plays. Curiously, Menander's characters avoid maxims at just the point at which they have acquired greater knowledge and understanding. It is also surprising that they do not utter maxims towards the end of speeches or scenes, even though this was a common enough structural technique elsewhere. All of this implies that none of the maxims is to be accorded any more weight or emphasis than any other, and it may be thought to add to the overall sense of inconclusiveness.

Let us examine the maxims in one particular play - the Epitrepontes - as a way of illustrating these tendencies. ${ }^{31}$ The first, on the subject of idleness, appears towards the start of Act II. The papyrus text is badly damaged at this point, but the maxim can be completely restored because it was also preserved as an independent quotation/fragment by the anthologizer Stobaeus. ${ }^{32}$

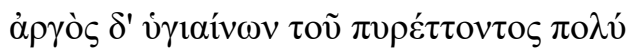

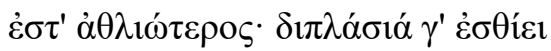

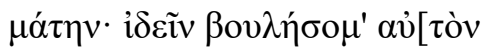

An idle man in good health is much more of a wretch than one who's suffering from a fever, since he eats twice as much but to no avail. I'll see him if I get my way...

${ }^{30} \mathrm{Cf}$. Arist. Rhet. $1395 \mathrm{a} 2-7$ for the view that $\gamma v \omega \mu \mathrm{o} \lambda \mathrm{o} \gamma \varepsilon \tilde{\mathrm{v} v}$ is more appropriate for older speakers.

${ }^{31}$ I omit from the discussion two book fragments (frr. 1-2 Sandbach = Orion, Anth.

7.8, Stobaeus 4.29.58) which cannot be placed within the plot of the play as it stands; but see Ireland (2010) 261-2.

${ }^{32}$ P.Oxy. 4641 (overlapping with the book-fragment preserved at Stobaeus 3.30.7): see Nünlist (1999). Cf. also Furley (2009) 139-41, who prints the lines as 'Act II, 12 15'; Ireland's text (2010) numbers them as lines 207-9. (Sandbach had previously included the lines as 'fr. 6'.) 
The speaker is the old miser Smikrines. At this point in the plot he is complaining about the behaviour of his good-for-nothing son-in-law, Charisios, who has abandoned his wife and gone next door to live an life of idleness and debauchery. Smikrines invokes the maxim as a way of criticizing Charisios' behaviour by reference to general principles, which is perfectly reasonable. But his choice of maxim also characterizes Smikrines himself, for it is particularly amusing to see a miser worrying about someone over-indulging at another person's expense. In fact Smikrines has already complained about Charisios' wine-drinking, not so much because of his drunkenness but specifically because of the cost of the wine (127-31), and he has also expressed horror at the fees charged by Charisios' pimp (136-7; cf. 749-50 on the expenses involved in festival attendance). In other words, what is presented by the speaker as a general moral observation about idleness is inherently mixed up with the specifics of the situation and the character of the speaker. In addition to the primary subject-matter, there is also an implicit secondary subject (penny-pinching), and the moral arbiter himself unwittingly becomes a target of criticism.

The character of the speaker is also an important factor in the next example (232-6). Here the charcoal-burner Syriskos is attempting to persuade Smikrines to act as impartial arbiter in his dispute with the shepherd Daos.

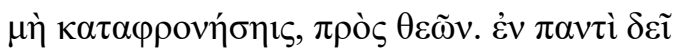

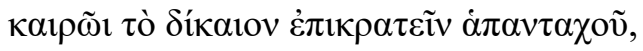

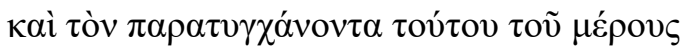

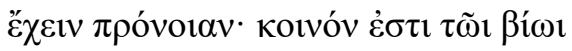
$\pi \alpha ́ v \tau \omega v$.

Don't look down on us, I beseech you. At all times, everywhere in the world, justice should prevail, and anyone who happens to be present should feel that they are involved: it is a duty common to everyone in this life.

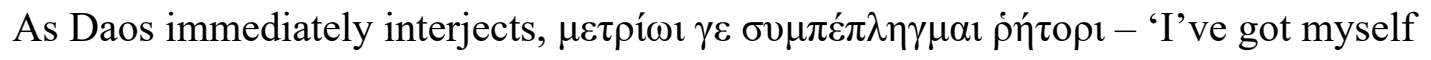
involved with a right proper orator!' - and indeed, as others have observed, it seems incongruous that Syriskos, an uneducated slave, should be presented as so acutely clever and so familiar with rhetorical techniques during this whole scene. Here the 
maxim is employed for persuasive ends, but it is the second half of the statement that is particularly striking. The speaker is really squeezing two separate points into a single maxim, starting off with an unexceptional and rather vague appeal to justice ( $\tau$ ò

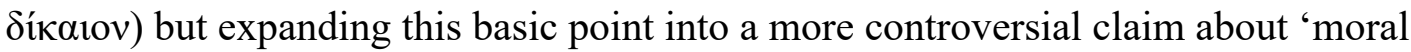
proximity' or the duties of the bystander. ${ }^{33}$ What is even more important is that Syriskos is transparently motivated by considerations of self-interest rather than, as he claims, by a concern for universal justice. He is really using the maxim as a cover for his own distinctly questionable conduct. The subject of the dispute is a collection of jewellery and ornaments that were abandoned along with the baby whom Daos found and whom Syriskos and his wife adopted, and the point is that Syriskos wants to keep these precious objects for himself.

A little later, Syriskos uses another maxim in his attempts to get hold of the trinkets. This time his argument is both ingenious and ludicrous. He now affects to believe that he and all the others are characters in a tragedy, and he points out (325ff.) that tragedies are full of stories of abandoned babies, long-lost relatives and recognition-scenes, in which tokens are vital to the resolution of the plot. In that case, Syriskos argues, it would be unfair to deprive this baby of a proper recognition-scene and its hope of deliverance and social prospects. It is precisely in this context that he deploys the next maxim (341-5):

$\gamma \alpha \mu \tilde{\omega} v \dot{\alpha} \delta \varepsilon \lambda \varphi \eta ́ v \tau \iota \varsigma \delta \grave{\alpha} \gamma v \omega \rho i ́ \sigma \mu \alpha \tau \alpha$

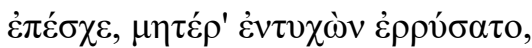
ह̌ $\sigma \omega \sigma^{\prime} \dot{\alpha} \delta \varepsilon \lambda \varphi o ́ v . ~ o ̋ v \tau^{\prime} \dot{\varepsilon} \pi 1 \sigma \varphi \alpha \lambda \tilde{\eta} \varphi v ́ \sigma \varepsilon 1$

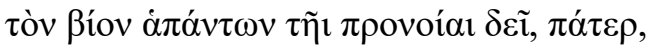

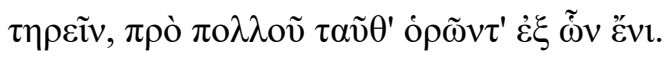

It was through recognition-tokens that one man refrained from marrying his sister, and another was reunited with his mother and rescued her, and another saved his brother. By nature the life of all people is precarious, good sir, so one must look after it with due foresight, with a view to how we might get the result we want above all else.

${ }^{33} \mathrm{Cf}$. the famous Terentian maxim homo sum: humani nihil alienum a me puto (Heaut. Tim. 77), which similarly appears to encapsulate the principle of 'moral proximity' (cf. Cic. De Off. 1.30, Sen. Epist. 95.52-3), but is actually an attempt by Chremes to justify poking his nose into other people's business. 
As before, what starts off as an unremarkable general observation - on the precarious nature of human life - is developed into a more complex proposition about foresight and the need to look after one's own interests. ${ }^{34}$ But this time the sentiment is undercut by the overt intrusion of metatheatricality and paratragedy. ${ }^{35}$ It is openly acknowledged that the scenario is not real life but a play, with strong generic affinities to tragedy (even though we are still in a comedy); the precious objects have become dramatic props or 'recognition-tokens' ( $\gamma \nu \omega \rho i ́ \sigma \mu \alpha \tau \alpha)$, as if Syriskos already knows that there is a recognition-scene coming up in the next act; and the maxim itself might be seen as paratragic in its language and tone. ${ }^{36}$ Several sets of 'inverted commas' are simultaneously in play here, and thus it is hard to read the content of the maxim unironically.

Syriskos is not the only character to behave as though he is in a play, nor is he the only one to use maxims in a paratragic manner. An even more striking example is provided by the slave Onesimus, who quotes a genuine tragic maxim towards the end of Act V (1123-6) when he is trying to explain the plot to Smikrines:

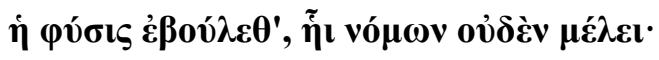

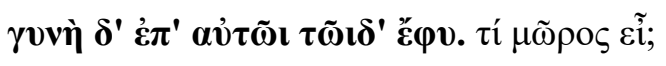

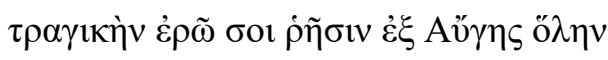

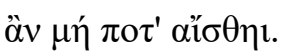

\footnotetext{
${ }^{34}$ There is also a degree of ambiguity: should one take the words $\dot{\alpha} \pi \alpha \dot{v} \tau \omega \nu \tau \tilde{\eta} \iota$ $\pi \rho o v o i ́ \alpha 1$ together, meaning 'foresight of everything'? To what does $\tau \alpha \tilde{v} \theta$ ' refer? See Verdenius (1974).

${ }^{35}$ On the use of paratragic motifs here (and elsewhere in Menander) see Cusset (2003) 183-7; Gutzwiller (2000) 105-6, 111-13.

${ }^{36}$ Metrically and in its expression the maxim seems more tragic than comic: its language is 'elaborately turned' and includes the 'high' (epic or tragic) form

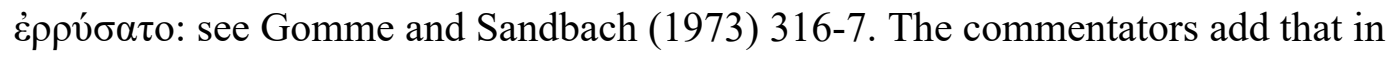
general throughout this scene 'Syriskos' style keeps rising towards that of tragedy...but never quite maintains the tragic level; $\ldots$ when he thinks of the real world, comic metre comes rushing back.'
} 
'It was the will of nature, which cares nothing for laws; woman was born for this very thing, ${ }^{37}$ How can you be so foolish? I'll quote you the whole tragic speech from Auge, if you haven't grasped it by now!

The function of this quotation is much the same as Syriskos' earlier remarks about the parallels between the current situation and the world of tragedy. We are being reminded, none too subtly, that the plot of Epitrepontes is uncannily similar to that of Euripides' Auge (in which Auge was raped by Heracles and gave birth to a child who was later recognized by means of a ring). In this case the specifically gnomic properties of the quotation are almost irrelevant; it is the literary genre and the specific source of the verses that we are supposed to notice, rather than the fact that this is a maxim. We may also notice the fact that Onesimus, like Syriskos, although a slave, is conversant with literature and able to conjure up an apt quotation for every occasion. As often, it is the 'wrong' character who acts as the voice of knowledge and wisdom, while those of superior status and education are seen as helpless fools. A few lines earlier Onesimus had already demonstrated a certain moral authority by supplying Smikrines with another maxim about the importance of a man's inner character (1092-9):

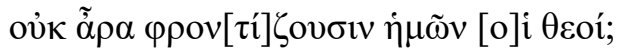

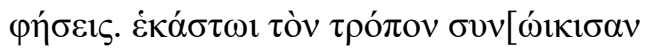

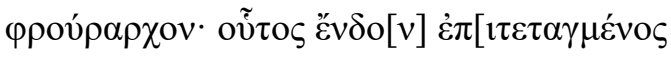
$\dot{\varepsilon} \pi \dot{\varepsilon} \tau \rho \iota \varepsilon \varepsilon, \grave{\alpha} v \alpha \hat{v} \tau \tilde{\omega} 1 \kappa \alpha \kappa \tilde{\omega} \varsigma \chi \rho \eta[\sigma \omega ́ \mu \varepsilon \theta \alpha$,

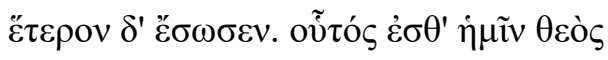

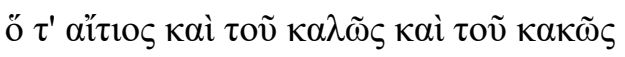
$\pi \rho \alpha ́ \tau \tau \varepsilon v v \dot{\varepsilon} \kappa \alpha ́ \sigma \tau \omega t \cdot \tau o \tilde{v} \tau o v$ i $\lambda \alpha ́ \sigma \kappa o v \pi \mathrm{o} \tilde{V}$

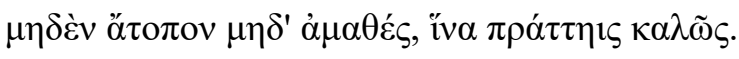

Will you say, then, that the gods don't care for us? But they've placed our character to dwell in each of us as our commander: once it has been assigned to its post within us, it brings us down if we mistreat it, but in another case it might bring salvation. Character is our god, and it is responsible for each person's fate, both good and ill. If you want to fare well, you must please it by not doing anything inappropriate or foolish.

${ }^{37}$ Eur. Auge fr. 920 Kannicht. 
More than any of the other maxims in the play, this may seem to invite us to read it completely 'straight'. It has been interpreted as a variant on the concept of the guardian daimon or guiding spirit, found in other (perfectly serious) philosophical writings. ${ }^{38}$ Yet here too it appears that the sentiments expressed in the maxim are being undermined, either by their incongruous appearance in the mouth of a comic slave, or by a certain logical inconsistency (if our character is responsible for our actions, how can we choose to 'please' it by our own choice of actions?), or by the fact that with this theory Onesimos is controversially rejecting the gods and conventional religious wisdom (cf. 1081-9). In addition, one notes that the deliberate mangling or oversimplification of philosophical concepts seems to have been a recurrent topos of comic maxims: one can identify many similar examples from other comedies, which typically reject serious philosophy in favour of homely popular wisdom. ${ }^{39}$

The only other maxim in the play (793-6) is spoken by Smikrines to his daughter, Pamphile, when he is warning her that she is in danger of being displaced in her husband's affections by a courtesan:

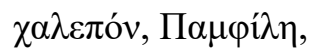

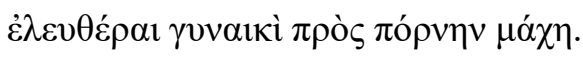

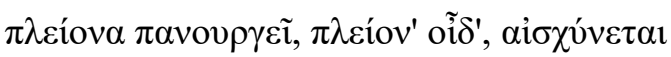

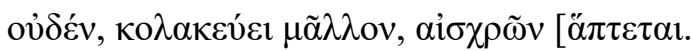

${ }^{38}$ Ireland (2010) 258 compares Heraclitus fr. 119 D-K, Epicharmus fr. 266 K-A and Seneca Epist. 41.2 as well as Menander fr. $500 \mathrm{~K}-\mathrm{A}$, though he concludes that this is 'essentially a mishmash of ideas from a slave'. Cf. Gomme and Sandbach (1973) 378: 'Onesimos' philosophy here will not stand up'.

39 e.g. Alexis, Asotodidaskalos fr. 25 (reduction of Epicureanism to simple hedonism); Baton, Androphonos fr. 3, Philemon, Pyrrhus fr. 74 (ridicule of 'the Good');

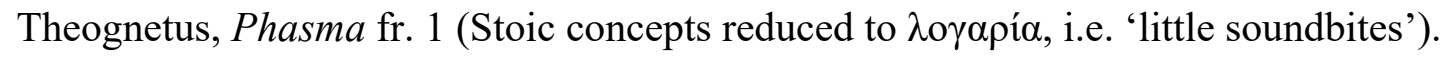
Cf. Arist. Rhet. 2.1395a6-7 and fr. 13 Rose for the idea that philosophers rejected the popular gnomic tradition and, conversely, that maxims are the property of ordinary people. See also Dover (1974) 269. 
It is difficult, Pamphile, for a free-born woman to join battle with a whore: she is capable of more mischief; she knows more; she has no shame; she is better at flattery; she behaves disgracefully.

As frequently elsewhere, the maxim is being employed as a tool for persuasion. This particular example, like the last, initially seems straightforward and unproblematic: it presents itself as an expression of a conventional misogynistic topos (and it was treated as such by the fourth-century bishop who later quoted the lines out of context) ${ }^{40}$ But in fact - like all the other maxims in this play - its literal value as a statement of universal wisdom is undermined by the development of the plot, for we will shortly see that Habrotonon, the 'whore' in question, is a thoroughly good and sympathetic character. She is kind and supportive to Pamphile, she is instrumental in bringing about the reconciliation between Pamphile and Charisios, and she is generally quite unlike the stereotypical scarlet woman that we might have expected. ${ }^{41}$ Thus Smikrines' conventional wisdom is revealed as completely inadequate to deal with the situation.

It would be unsafe to regard Epitrepontes as typical of the whole comic genre in its use of maxims; other lost plays and different authors may have handled things very differently. ${ }^{42}$ Nonetheless, it is highly suggestive that the apparent meaning of every single maxim in this play is modified, undermined or ironized by its dramatic setting.

\section{WINE AND 'WISDOM'}

\footnotetext{
${ }^{40}$ Palladius, Dialogue on the Life of Chrysostom $\$ 94$. Furley (2009) compares
}

Menander fr. 860; many other comic and tragic maxims depict women as cunning and devious.

${ }^{41}$ See Ruffell (2014) 156-9 on Menander's subtle and unconventional deployment of 'stock' characters, including Habrotonon; cf. Hurst (2015) 24-7 and Arnott (1979) xxxii-xxxviii.

${ }^{42}$ Nevertheless, Cusset and Lhostis (2011) reach similar conclusions in relation to Dyskolos, Samia and Aspis. 
As I observed above, comic maxims range widely across the subject matter of Greek popular morality, but one topic in particular - wine - is especially well represented..$^{43}$ No doubt this partly reflects the fact that many of our fragments come from Athenaeus. But it is also unsurprising in view of the thematic preoccupations of the genre. After all, many comedies, from all periods, feature a pronounced sympotic or komastic element, and there is much talk of drinking and getting drunk. ${ }^{44}$

Gnomic wisdom relating to wine is not exclusively the property of comedy - it can be found in Homeric epic, lyric poetry and sympotic elegy - but comedy transforms the theme in an idiosyncratic way. Sometimes we might find comedians explicitly challenging traditional ideas from the world of the symposium, as in a passage from Anaxandrides (Thesauros fr. 18) where a character rejects (or revises) the proverbial content of an old drinking-song:

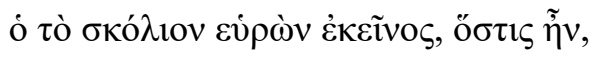

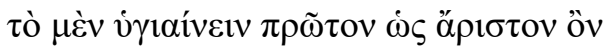

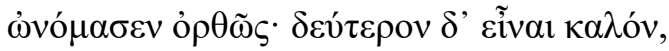

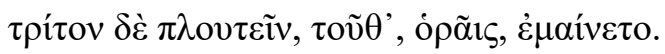

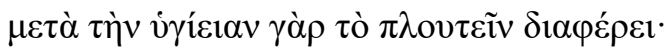

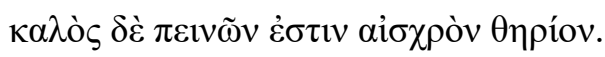

That fellow who came up with the skolion, whoever it was, he really put his finger on it when he said that the first and best thing was for a person to be healthy. But as for claiming that the second best thing was to be good-looking and the third best to be rich - well, you see, in that respect he was insane! No, after health it's being rich that stands out as next best; and a hungry man who happens to be good-looking is still a terrible creature. $^{45}$

${ }^{43}$ Alexis frs. 45, 82, 88, 257, 273, 280; Amphis frs. 8, 29, 33, 37, 41; Antiphanes frs. 42, 228, 232, 238, 250, 268; Aristophanes Knights 88; Axionicus fr. 5; Clearchus fr. 3; Cratinus fr. 203; Crobylus fr. 3; Ephippus fr. 25; Eubulus frs. 93, 133; Menander Samia 340-4, Ophelion fr. 4 [= Eubulus fr. 33]; Philemon frs. 104, 162.

${ }^{44}$ On the genre's vinous leanings see Bowie (1997), Pütz (2003), Wilkins (2000) 20213.

${ }^{45}$ Cf. PMG 890 (also Pl. Gorg. 451e, Arist. Rhet. 2.21.1394b13, Athen. 15.694e) for the original skolion, which Aristotle (Rhet. 2.21.1394b13) treats as conventionally accepted opinion ( 
But more often what we see in comedy is a series of playful bons mots formulated from the viewpoint of the bon viveur. Wine is repeatedly presented as a vital component of human existence: it boosts the intellect; it gives one special abilities that one did not possess before; it improves one's conversation; it is akin to poetic inspiration; its effect on the drinker is compared to the watering of a plant. ${ }^{46}$ Above all, however, it is alcoholic excess, rather than moderation and good sense, that is recommended in these maxims - as in the following example (Amphis, Philadelphoi fr. 33):

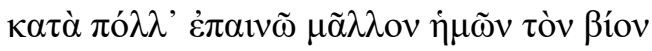

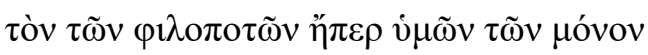

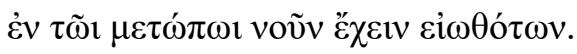

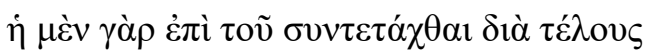

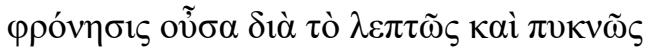

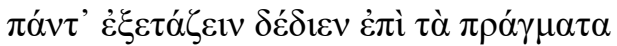

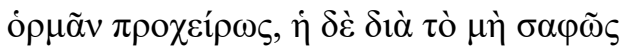

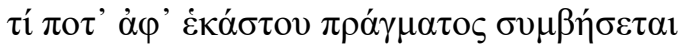

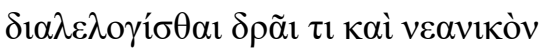

$$
\begin{aligned}
& \text { каì } \theta \varepsilon \rho \mu o ́ v . . .
\end{aligned}
$$

There are many reasons why I want to praise the life of us bibulous folk, in preference to your life, you whose heads are wont to contain nothing but sober sense. Why, your way of thinking, being disposed to examine everything thoroughly and carefully, is afraid to go with its impulse and rush into things; but our way of doing things, on the other hand, because it doesn't calculate the precise outcome of every eventuality, can achieve something fresh and spirited...

362 (a proverb is quoted within a longer maxim, and the speaker distances himself from the sentiment of the original proverb); Ephippus fr. 25 also seems to be arguing

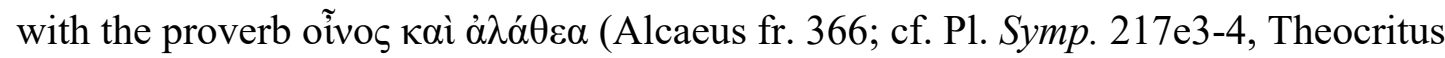
29.1-8).

${ }^{46}$ e.g. Ephippus fr. 25, Cratinus, Pytine fr. 203, Amphis fr. 41, Alexis fr. 285, Ar. Knights 88. 
Here, as so often, the maxim is being used in order to persuade or exhort the listener, but the speaker is a drunkard and his interlocutor is a sober, sensible character. This is obviously another variation on the familiar comic pattern of maxims appearing in the mouths of the 'wrong' people. Can one take the advice of inebriated people entirely seriously?

Occasionally, it is true, the dangers of strong drink are acknowledged, as in

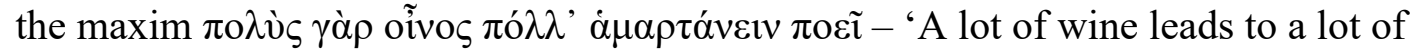
mistakes' (Alexis, Epitropos fr. 82). In fact, overindulgence and its after-effects seem to have provided a stock theme, as illustrated by the following nearly identical maxims from different authors:

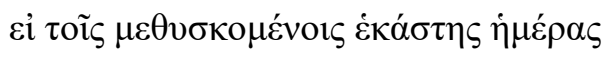

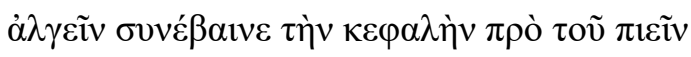

$\tau$

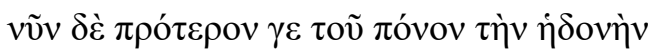

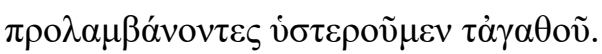

If people who get drunk every day suffered their hangover before drinking unmixed wine, not a single one of us would ever have had a drink. But as it is, we enjoy the pleasure before the pain, and so we miss out on what's good for us (Clearchus, Corinthioi fr. 3).

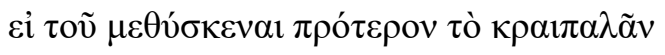

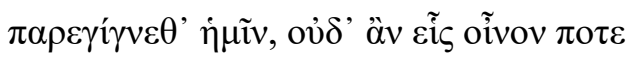

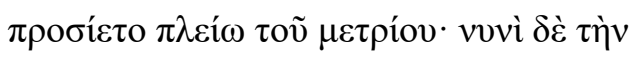

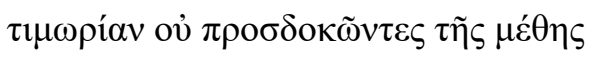

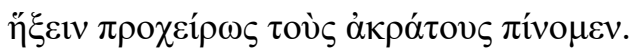
If we suffered the hangover before getting drunk, not a single one of us would ever drink more than his recommended limit of wine. But as it is, we don't expect to get punished for being drunk, and so we eagerly guzzle down the unmixed wine (Alexis, Phrygian fr. 257).

Lines like this are funny because almost everyone can relate to them from personal experience - and, of course, the hangover has proved a mainstay of humour for comedians throughout the centuries, from Cratinus to Lucky Jim - but it can scarcely be said that maxims of this sort represent 'traditional wisdom' in the way that we 
would normally expect. In this category of maxims if nowhere else, it is obvious that the comedians are playing around with the traditional form, using it as a vehicle for unorthodox content. The sentiments in question appear (once again) inside ironical inverted commas, since jocular or outré opinions are merely masquerading as wisdom.

\section{COMIC VERSUS TRAGIC WISDOM}

I have suggested that the maxim may be treated as a literary genre with which comedy is in dialogue. But another genre - tragedy - is arguably even more significant as a point of reference or departure. As we have already seen, tragedy was routinely treated as a genuinely authoritative source of wisdom and a repository of maxims. One of the most interesting categories of comic maxims consists of verses in which the comedians are openly engaging in dialogue with tragic maxims by explicitly quoting, adapting or parodying specific tragic sources. In these examples, perhaps, we are witnessing not just a dialogue but a contest of comic versus tragic wisdom. ${ }^{47}$

A number of comic maxims are created by taking well-known tragic maxims and altering some aspect of them so that they become preposterous. For example, the

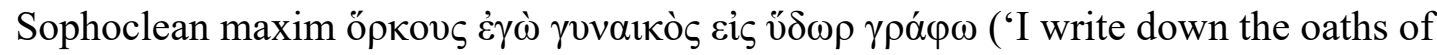

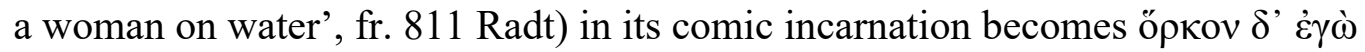

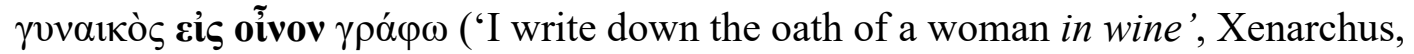
Pentathlos fr. 6). Xenarchus has retained the traditional form, the quotationality, and the authoritative tone of the original, but he has tweaked the content to provide an unexpected punchline. Of course, turning water into wine is thoroughly in keeping with the jocular, boozy moralizing that characterizes the genre (see above), and thus the maxim has now become distinctively comic. The comedian has 'improved' tragedy, rewriting it in a way that is more in keeping with his own generic preoccupations.

Xenarchus' humour depends on the fact that the Sophoclean maxim was already current as a famous quotation and would have been recognized as such by his

\footnotetext{
${ }^{47}$ Cf. Mauduit (2011), who shows that Aristophanes treats maxims as one among a number of tragic conventions which he seeks to criticize; Wright (2012) 150-6 makes a similar point about gnomic citations from tragedy in old comedy.
} 
audience. A similar effect is seen elsewhere, as in the opening (fr. 1) of Eriphus' lost comedy Aeolus, the title of which suggests a sustained interest in tragic parody.

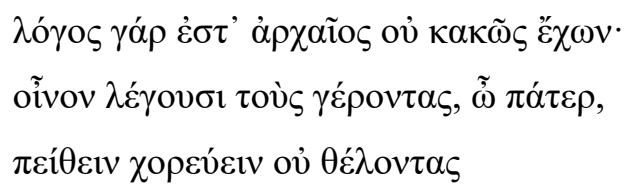

There is an ancient saying, which isn't at all bad: they say, father, that wine persuades old men to dance, even if they don't want to...

Here the maxim is explicitly framed as a quotation (logos) from some other source, and the speaker is apparently vouching for its authority, although the litotes (ov $\kappa \alpha \kappa \tilde{\omega} \varsigma \check{\varepsilon} \chi \omega v)$ seems to hint that his tone is somewhat tongue-in-cheek even before the saying has been quoted. In fact Eriphus is parodying Sophocles, not in the content of the maxim but in the way that the maxim is introduced. Eriphus is drawing our attention to the fact that it was unusual and striking for a play to begin with a maxim, as the source text, Sophocles' Trachiniae, had done. ${ }^{48}$ The first lines of this tragedy, spoken by Deianeira, are:

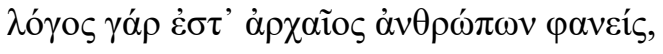

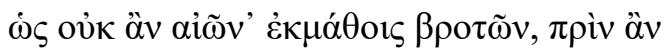

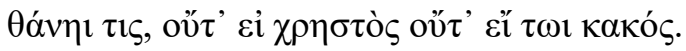

There is an ancient saying, well known to mankind, that you cannot rightly assess a person's life, so as to know whether it is good or bad, before it comes to its end.

These words, boldly positioned right at the start of the prologue, look remarkably like an epigraph in terms of their interpretative function and their relationship to the rest of the tragedy. They are ostensibly programmatic, suggesting that they are (somehow) thematically important for understanding the drama that follows, but at the same time they are provocative and challenging, inviting disagreement or debate. ${ }^{49}$ Even in the original version, the maxim is already a quotation, and its speaker explicitly distances

\footnotetext{
${ }^{48}$ Soph. Trach. 1-3; the only other surviving examples of this technique are Eur. Aeolus fr. 13a, Hcld. 1-6, Or. 1-3, Phoenix fr. 803a, Stheneboea fr. 661.

${ }^{49}$ See Wright (2016) on quasi-epigraphic lines.
} 
herself from the utterance. Deianeira attributes it to other people (or to an anonymous voice of tradition), and she goes on to say that her own personal experiences make her doubt the truth of the saying. In Eriphus' comic version nothing remains of the original maxim except, as it were, the quotation marks. The comedian is drawing our attention not to the meaning of the Sophoclean maxim but specifically to its function and form (as a provocative opening device and as an example of the complexity of quotation culture). The specific content is new. As in the previous example, sober tragic moralizing has been replaced by tipsy comic wisdom (or rather, 'wisdom' - in inverted commas).

Elsewhere Antiphanes (fr. 228) riffs on another Sophoclean theme, mixing together a well-known quotation from Antigone with a gnomic pronouncement of his own on the meaning of life:

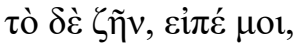

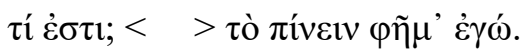

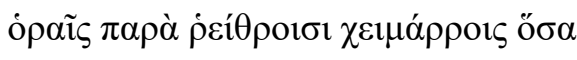

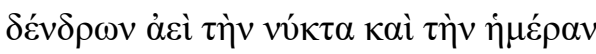

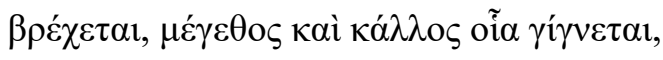

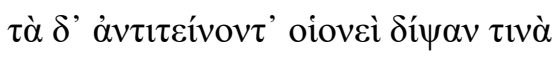

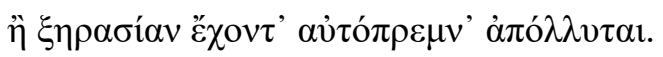

Life! - what is it, pray tell? Life is drinking, say I. Do you see how the trees beside fast-flowing torrent streams stay well-watered at all times of the day and night, and how tall and attractive they grow, but those that resist, those that are dry and parched, are destroyed root and branch...
}

The comic and tragic verses are run together as if they formed a single utterance. ${ }^{50} \mathrm{In}$ fact the Sophoclean lines (Ant. 712-15) are not strictly gnomic, but they contain a

\footnotetext{
${ }^{50}$ For the same cut-and-paste technique cf. Menander fr. 602 K-A and incert. fab. fr. 4 Sandbach, both of which passages incorporate Euripidean material alongside Menander's own words in the service of consolation or gnomic advice. Plut. Consol. ad Apoll. 5, 103b, who preserves the quotation, apparently treats both authors side by side as sources of ethical wisdom. Cf. also Antiphanes, Traumatias fr. 205, which
} 
simile that obviously struck readers as vivid and memorable. Antiphanes is not the only comedian to make use of the quotation: not long after its original appearance it was already being parodied by Eupolis. ${ }^{51}$ As often in comedy, half the fun lies in quotation-spotting. ${ }^{52}$ Any spectator or reader familiar with Antigone would have been aware that the quotation originally belonged to a speech by Haemon, in which he vainly tried to persuade his father to be less obdurate, but in its new context the lines are manipulated so as to produce a quite different meaning. The streams and torrents of the Sophoclean simile are treated as if they literally represented streams of wine, and the image is used to illustrate the 'truth' that life and wine are synonymous. Thus the boundaries between quotation and original, tragedy and comedy, serious and silly, are blurred. Perhaps Antiphanes might also be seen as using this maxim to draw our attention implicitly to the problems of excerption as a reading practice, highlighting the way in which readers tend to take quotations out of context and distort them for their own ends.

The contrast between selective excerption and complete sequential reading of texts was made fully explicit in a scene of dialogue in Diphilus' Synoris (fr. 74).

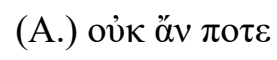

Eủ

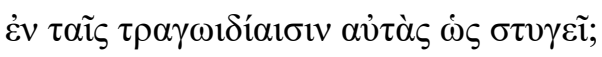

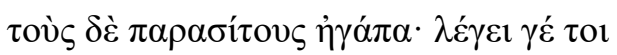

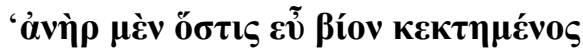

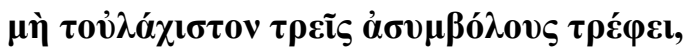

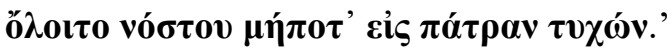

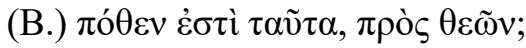

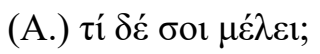

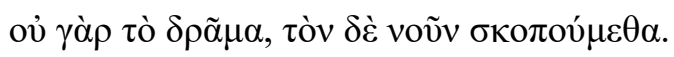

(A.) Euripides would never save a woman: don't you see how he hates them in his tragedies? However, he really likes parasites! Why, indeed, he says: 'The man who is in possession of a good livelihood but doesn't feed at least three folk who can't pay

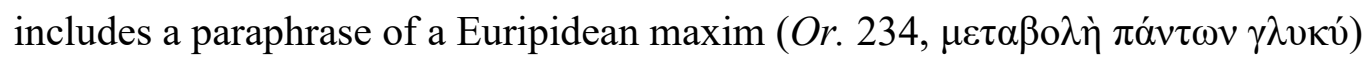
within Antiphanes' own sentence structure.

${ }^{51}$ Eupolis fr. 260. 23-6: see Storey (2003) 233-8.

${ }^{52}$ See Wright (2012) 143-62. 
their own way, let him perish on his journey home and never manage to get back to his native land.'

(B.) Where the hell are those lines from?

(A.) What is it to you where they're from? We're not looking at the play but at the sense.

The maxim is being used specifically to illustrate the contrast between these two different modes of reading. The person doing the quoting is a parasite, who is appropriating the quotation for his own ends (which, as usual, involve persuasion or manipulation). He is not concerned with Euripides' original meaning, whatever that may have been. Once again, the joke here works by mobilizing the audience's knowledge of literature. Those who were well-read in tragedy will have realized, firstly, that the source of the quotation was Euripides' Antiope, and secondly, that the parasite has deliberately altered the quotation to suit his own interests. The original lines were as follows:

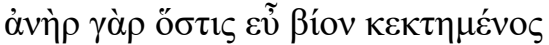

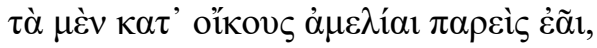

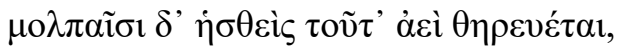

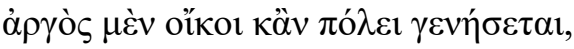

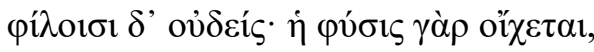

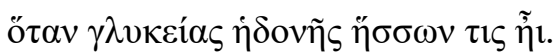

The man who is in possession of a good livelihood but ignores matters in his house and neglects them, delighting in musical activities and constantly pursuing them instead, will become idle both at home and in the city, and to his friends and family he will cease to exist - for a person's nature is lost whenever he is overcome by sweet pleasure. $^{53}$

Those who recognized this quotation may have remembered that it formed part of the character Zethus' strictures against idleness and self-indulgence. If so, they will have

\footnotetext{
${ }^{53}$ Eur. Antiope fr. 187 Kannicht (preserved by Stobaeus 3.30.1). On the clash between Zethus and Amphion, and the 'sophistic' concerns that formed the basis for Antiope's plot, see Collard and Cropp (2005) 259-329. Both brothers tend to articulate their (diametrically opposed) views in the form of maxims: see esp. frs. 183-9, 193-8.
} 
found it hilariously incongruous that an idle parasite should be quoting the lines out of context in support of his own way of life. It may also have occurred to some of them that in its original context the Euripidean maxim was not presented neutrally as a universal moral principle. Rather, it was a provocative contribution to an unresolved ideological debate: Zethus represented social and political pragmosyne, in stark opposition to his brother Amphion, who advocated leisure, artistic pursuits and political quietism.

In the comic version, only the first verse from Antiope is retained. The second verse is a paratragic pastiche representing the parasite's own thoughts, and the third verse is taken from a completely different Euripidean play (Iphigenia among the Taurians 535). Diphilus, like Antiphanes, has run together several sources to produce a seamless tragicomic mash-up which (just about) makes sense on its own terms but is utterly bizarre. He then challenges his audience to identify the source(s) of the

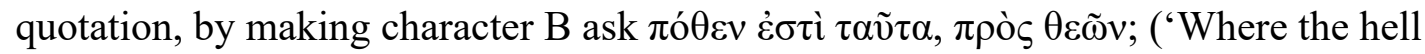
are those lines from?') Essentially this is a tantalizing quiz question to which no answer is supplied: it is up to the audience to fill in the blanks for themselves. ${ }^{54}$ But the point is that maxim-collecting and quotation culture are being treated by Diphilus, in a sophisticated and multi-layered manner, as subjects of humour in their own right.

All of these traits - the quotation and subversion of tragedy, the ostentatious deployment of literary knowledge, and the ironical attitude towards decontextualized quotation - can be seen to underpin the humour in our final example (Nicostratus fr. 29):

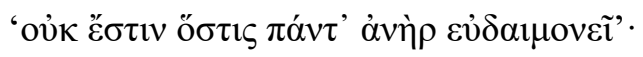

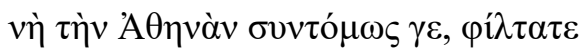

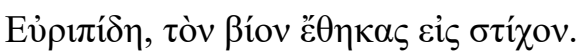

'No man exists who is fortunate in every respect...' Yes, by Athena, that's right!

Dearest Euripides, how very neatly you have managed to put the whole of life into one line.

\footnotetext{
${ }^{54}$ Cf. a similar technique in Antiphanes, Traumatias fr. 205, where characters argue about whether quotations are taken from Euripides or Philoxenus, before concluding

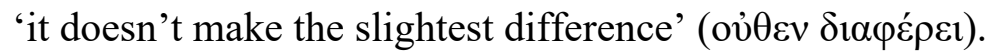


Here Nicostratus' character is quoting (without attribution) a verse from Euripides' tragedy Stheneboea that had already become famous within antiquity as a freefloating maxim..$^{55}$ The original source of the line and its sentiment are apparently irrelevant in its comic setting. What matters is the speaker's obvious sarcasm and the underlying attitude that it denotes. The idea that the meaning of life can really be summed up in a dinky quotable soundbite, as Euripides seems to do, comes to seem ludicrous.

All these comic passages reflect the popular culture of the fifth and fourth centuries, and they provide evidence for the contemporary status of tragedy - as classic literature, as representative of 'high' culture in contrast with the 'low' genre of comedy, as source of moral wisdom and authority, and as repository of maxims par excellence. It seems clear that when comedy itself uses maxims, as it does more and more frequently from the fourth century onwards, it does so in a way that simultaneously emulates and mocks tragedy's status and authority.

\section{CONCLUSION}

Faced with dozens of stray quotations (a.k.a. fragments) and hardly any dramatic contexts in which to situate them, we will find it impossible to reach a wholly definitive conclusion. As always when dealing with fragmentary texts, caution is needed; generalizations must be carefully qualified; we need to allow for the possibility that our ideas may be quite wrong. Nevertheless, this article has aimed to establish two important points. First, it is clear that quotable maxims are a very distinctive feature of later Greek comedy, marking a significant new development from comedy of the fifth century. Second, it has been argued that the concept of 'inverted commas' can in several different senses bring us closer to understanding how maxims function within comedy. Even when we have only decontextualized fragments in front of us, the 'inverted commas' approach can offer us a possible way of making sense of them - and this way strikes me as considerably more convincing (that is to say, more intellectually satisfying and better nuanced) than any straightforwardly literal readings of their content.

\footnotetext{
${ }^{55}$ Eur. fr. 661 Kannicht: cf. Wright (2016).
} 
On the basis of the discussion above, it emerges that many (I do not say all) comic maxims can be read in a way that is jocular or ironical rather than serious and literal. The traditional form of the quotable maxim allows the comedians to lay claim to serious ethical concerns, but they often turn out to be playing a game with their audiences. The specific content of these maxims, or the mode in which they are deployed, encourages us to question any authority that they might appear to possess. These utterances might seem to embody confident general statements of truth or universal wisdom, but in fact they are usually much more provisional or provocative.

It remains possible (I concede) that some of these comedians may have been deadly earnest in their ethical aims, but it is hard to find a single definite example of this among our sources. What we have found, time after time, is that these poets are trying to make us laugh - at traditional popular wisdom, at other genres of literature that seem to embody wisdom, at over-simplistic attempts to unearth an author's meaning or moral message in a text, or even at quotation culture itself. In this respect, they are comparable to that other extraordinary aphorist, Oscar Wilde, to whom I give the last word: 'Art is the only serious thing in the world. And the artist is the only person who is never serious'. ${ }^{56}$

\section{Bibliography}

Arnott, W.G. (1979) (ed.), Menander: I, Cambridge, MA.

Arnott, W.G. (2000) 'On editing fragments from literary and lexicographic sources', in F.D. Harvey and J.M. Wilkins (eds.), The Rivals of Aristophanes: Studies in Athenian Old Comedy, London and Swansea, 1-13.

Bain, D.C. (1983) (ed.) Menander: Samia, Warminster.

Bakola, E., Prauscello, L., and Telò, M. (2013) (eds.) Greek comedy and the discourse of genres, Cambridge.

Barigazzi, A. (1965) La formazione spirituale di Menandro, Turin.

Bosher, K. (2014) 'Epicharmus and early Sicilian comedy', in Revermann (2014), 79-94.

Bowie, A.M. (1997) 'Thinking with drinking: wine and the symposium in Aristophanes', JHS $117,1-21$.

Cinaglia, V. (2014) Aristotle and Menander on the Ethics of Understanding, Leiden.

\footnotetext{
56 'A few maxims for the instruction of the over-educated', The Saturday Review (17 November 1894).
} 
Collard, C. and Cropp, M.J. (2005) (eds.) Euripides: Selected Fragmentary Plays II, Oxford. Cusset, C. (2003) Menandre ou la comédie tragique, Paris.

Cusset, C. and Lhostis, N. (2011) 'Les maximes dans trois comédies de Ménandre', in Mauduit and Paré-Rey (2011), 93-108.

Dover, K.J. (1974) Greek Popular Morality, Oxford.

Empson, W. (1930) Seven Types of Ambiguity, London.

Farmer, M. (2017) Tragedy on the Comic Stage, Oxford and New York.

Furley, W. (2009) (ed.) Menander, Epitrepontes, London.

Garber (2003) Quotation Marks, London and New York.

Genette, G. (1997) Palimpsestes, Paris.

Gomme, A.W. and Sandbach, F.H. (1973) Menander: A Commentary, Oxford.

Green, P. (1990) Alexander to Actium, Berkeley.

Gutzwiller, K. (2000) 'The tragic mask of comedy', ClAnt 19, 102-37.

Hunter, R. (2014) Hesiodic Voices, Cambridge.

Hurst, A. (2015) Dans les marges de Ménandre, Paris.

Ireland, S. (2010) (ed.) Menander: The Shield and the Arbitration, Oxford.

Konstan, D. (2011) 'Excerpting as a reading practice', in G. Reydams-Schils (ed.), Thinking Through Excerpts: Studies in Stobaeus, Turnhout, 9-22.

Kramer, M. (2003) (ed.) La comédie de proverbes: pièce comique: d'après l'édition princeps de 1633, Paris.

Kurke, L. (2002) 'Gender, politics and subversion in the Chreiai of Machon', PCPS 48, 20 65 .

Lardinois, A. (2006) 'The polysemy of gnomic expressions in Ajax's deception speech', in I. de Jong and A. Rijksbaron (eds.), Sophocles and the Greek Language, Leiden, 213-23. Liapis, V. (2002) (ed.) Menandrou gnomai monostichoi, Athens.

Martin, R.P. (2011) 'Gnomes in poems: wisdom performance on the Athenian stage', in E. Karamalengou and E.D. Makrygianni (eds.), Antiphilesis: Studies on Classical, Byzantine, and Modern Greek Literature and Culture, Stuttgart, 116-27.

Mauduit, C. and Paré-Rey, P. (2011) (eds.) Les maximes théâtrales en Grèce et à Rome: transferts, réécritures, remplois, Paris.

Mauduit, C. (2011) 'Les poètes tragiques "forgeurs de sentences” dans les comédies d'Aristophane', in Mauduit and Paré-Rey (2011), 69-92.

Morson, G.S. (2011) The Words of Others: From Quotations to Culture, New Haven. Morson, G.S. (2012) The Long and the Short of It: From Aphorism to Novel, Stanford. Nervegna, S. (2013) Menander in Antiquity: The Contexts of Reception, Cambridge.

Nünlist, R. (1999) 'Ein neu identifiziertes Buchfragment aus Menanders Epitrepontes', ZPE 128, 54-6. 
Olson, S.D. (2007) (ed.) Broken Laughter: Select Fragments of Greek Comedy, Oxford.

Perlman, S. (1964) 'Quotations from poetry in Attic orators of the fourth century BC', AJP

$85,155-72$.

Pernigotti, C. (2008) Menandri sententiae, Florence.

Pompello, G. (1997) (ed.) Menandrou sentenze: introduzione, traduzione, e note, Milan.

Powell, J.U. and Barber, E.A. (1929) New Chapters in the History of Greek Literature,

Second Series, Oxford.

Pütz, B. (2003) The Symposium and Komos in Aristophanes, Stuttgart.

Revermann, M. (2014) (ed.) The Cambridge Companion to Greek Comedy, Cambridge.

Ruffell, I.A. (2014) 'Character types', in Revermann (2014), 147-67.

Russo, J. (1997) 'Prose genres for the performance of traditional wisdom in ancient Greece:

proverb, maxim, apophthegm', in L. Edmunds and R. Wallace (eds.), Poet, Public and

Performance in Ancient Greece, Baltimore, 49-64.

Scafuro, A. (1997) The Forensic Stage, Cambridge.

Shapiro, S. (2000) 'Proverbial wisdom in Herodotus', TAPA 130, 89-118.

Storey, I.C. (2003) Eupolis, Poet of Old Comedy, Oxford.

Verdenius, W.J. (1974) 'Notes on Menander, Epitrepontes', Mnemosyne 37, 17-43.

Wilde, O. (2007) The Epigrams of Oscar Wilde, London.

Wilkins, J.M. (2000) The Boastful Chef: The Discourse of Food in Ancient Greek Comedy,

Oxford.

Wright, M.E. (2012) The Comedian as Critic: Greek Old Comedy and Poetics, London.

Wright, M.E. (2013) 'Poets and poetry in later Greek comedy', CQ 63, 603-22.

Wright, M.E. (2016) 'Euripidean tragedy and quotation culture: the case of Stheneboea

F661', AJP 138, 601-23. 